\title{
The Policy Gap. \\ Global Mental Health in a Semi-Peripheral Country (Portugal, 1998-2016)
}

This paper analyzes the impact of the hegemonic paradigm of global mental health $(G M H)$ on Portugal. We specifically argue that $\mathrm{GMH}$ in Portugal has effected a change of priorities in health policies, favoring the prevention and treatment of common mental disorders to the detriment of the deinstitutionalizing process. Diffused through the media, this model has negative effects, such as the medicalization of social suffering, the reorganization of mental health policy areas according to utilitarian criteria, and the risk of greater invisibility of users with serious psychiatric diagnoses. However, the GMH approach, bringing to the frontline the impact of all social policies on mental health, represents a new opportunity to politically address social suffering. Characterized as a semi-peripheral country, Portugal may be representative of observable trends in similar countries.

Keywords: Globalization. Mental health. Psychiatric reforms. Psychiatric epidemiology. Human rights.
Este artigo analisa o impacto do paradigma hegemônico da saúde mental global (SMG) em Portugal. Argumenta-se que a SMG em Portugal promoveu uma mudança de prioridades nas políticas de saúde, favorecendo a prevenção e o tratamento das desordens mentais comuns em detrimento do processo de desinstitucionalização. Difundindo-se nos media, este modelo tem efeitos negativos, ao contribuir para a medicalização do sofrimento social, o escalonamento de áreas de intervenção de acordo com critérios utilitaristas e o risco de uma maior invisibilidade dos usuários com diagnósticos psiquiátricos graves. Contudo, o enfoque da SMG no impacto do conjunto das políticas sociais sobre a saúde mental representa uma nova oportunidade para encarar politicamente o sofrimento social. Caracterizado como país semiperiférico, Portugal pode ser representativo de tendências observáveis em países similares.

Palavras-chave: Globalização. Saúde mental. Reformas psiquiátricas. Epidemiologia psiquiátrica. Direitos humanos.

\footnotetext{
(a) Centro de Estudos Sociais, Universidade de Coimbra. Colégio de S. Jerónimo, Largo D. Dinis, Apartado 3087. Coimbra. 3000-995. Coimbra, Portugal. tmarques@ces.uc.pt
} 


\section{Introduction}

In an article published in 2009 in the benchmark psychiatry journal The Lancet, and significantly entitled "Global mental health: a failure of humanity", Arthur Kleinman contrasts advances in mental health in the USA with the realities observed in poor countries ${ }^{1}$. Notwithstanding enduring stigma and widespread recourse to prisons as mental healthcare facilities, he states, "mental health care in the USA is finally receiving renewed attention and resources aimed at closing the gap in parity with the rest of health care" (p. 603). He further added that "[the] worst abuses of the mental-health-care system are undergoing near constant, if unsustained, reform and patients' rights are being better, if still not well, protected" (p. 603). Turning to the situation in poor societies, Kleinman expressed himself as follows: "Appalling, dreadful, inhumane - the worst of words pile on each other to name the horrors of being shunned, isolated, and deprived of the most basic of human rights." (p. 603).

Other leading authors in the field have voiced criticisms of the emerging discipline and policy model of global mental health (GMH). Tacking stock of a workshop held at the McGill University, Kirmayer and Pederson referred to an observed tension in $\mathrm{GMH}$ as follows ${ }^{2}$ :

Some of the disagreements and divergences of opinion in the debate on global mental health occur because opponents have in mind very different types of problems. For example, many proponents of $\mathrm{GMH}$ focus on the most severely mentally ill in low-income countries who currently receive little or no effective treatment and who may endure harsh conditions including long-term physical restraints, confinement, and noxious interventions that cause injury. On the opposite end, some critics of GMH focus on examples of people with milder cases of common mental health problems that overlap with everyday problems in living. (p. 12)

These articles suggest that analyses of the two ends of the spectrum between rich and poor countries might be characterized in relatively clear-cut terms. In technically high-income but still relatively peripheral countries, however, the mental health domain looks rather more contradictory and, perhaps due to this, analyses of the impact of GMH are scarcer. In this study, specifically observing the Portuguese case, we argue that the contrasting realities that co-exist in the psychiatric sector render the assessment of the impact of $\mathrm{GMH}$ particularly difficult.

In order to tackle some of these difficulties, we employ the concept of 'semi-periphery' as proposed by Boaventura de Sousa Santos and specifically applied to Portugal' ${ }^{3}$. According to Santos, semiperipheral societies attempt to mimetically accompany the hegemonic reforms of the central countries. However, these attempts clash with rationalities and practices that the paradigm of modernity terms 'pre-modern'. In this context, more than simply encountering resistance, the models of the center become combined with structures, practices and rationalities typical of the peripheral countries ( $p$. 47). This heterogeneity derives in part from the unaccomplished development of capitalism and modernity, the strong tutelage of the state and the strength and plurality of social assistance. The latter is particularly visible in the mental health sector in Portugal, where religious orders still take charge of a substantial proportion of psychiatric care, mostly with regard to chronic psychiatric patients. In addition, recent deinstitutionalizing trends have favored this feature by overburdening family and informal networks ${ }^{4}$ (p. 19).

As far as mental health is concerned, we may, more concretely, bear in mind the epistemological criticisms of the epidemiological model observed in $\mathrm{GMH}$. Among these, we may refer to its dependency on diagnostic-interviews performed by laypeople and based on constantly changing categories of mental disorders defined by the internationally dominant psychiatry, as well as the systematic elimination of social contexts ${ }^{5}$. This recourse to epidemiology translates local forms of social suffering into the language of mental health as diffused by the models of the center. Lastly, our perspective also takes into account the cultural critique developed by Kirmayer and Pederson ${ }^{2}$, based on the finding that $\mathrm{GMH}$ "is itself a product of international professional, economic, and political institutions". Therefore, "the priorities of global mental health have been largely framed by mental health professionals and their institutional partners mostly located in wealthy countries" (p. 760). 
While our approach is explicitly based on a critical perspective, we undertake close empirical analysis of the concrete $\mathrm{GMH}$ meanings and interventions in Portugal. Specifically, this study combines historical analysis of major reform programs and international documents, epidemiological studies and media articles. The criteria for including sources into this analysis may be summarized as follows: serving as officially recognized programs for the implementation of mental health reforms (e.g. national plans and legislation); holding a key role in the scientific argumentation supporting the reform (e.g. epidemiologic studies quoted by official sources); proving instrumental in the technical elaboration of reforms (published working documents, international directives and reports); disseminating expert assessments of the reform's accomplishments and its impending necessities in the media. We analyse these sources diachronically, looking at the interplay between their contents and their contexts, and specifically focusing on the vocabularies by means of which they described and elaborate their field of application. This implies the systematic observation of the changing ways in which they link social suffering and mental disorders. In addition, we analyse their incorporation, or their echoing, of international guidelines and, relatedly, the strategic re-prioritizing of mental health needs. This methodology thus enables us to diachronically observe the explicit and the subtle transformations of mental health policies as well as the ways in which, by mobilizing GMH references, these policies build up their legitimacy. This approach also allows us to identify positive lines of action in ongoing $\mathrm{GMH}$ projects.

\section{Globalizing Portuguese Mental Health}

In 1998, a new law established the framework for the long desired psychiatric "deinstitutionalization" in Portugal ${ }^{6}$. Coming into being, first and foremost, as a means of regulating compulsory internments, the Mental Health Act consecrated a few great principles in view of a fully-fledged reform of psychiatry and mental health care. Among these principles featured the promotion of primary, secondary and tertiary mental health, as well the preference for care in the geographical proximity of services users. This law also established the aim of integrating psychiatry into general hospitals, a measure that went hand in hand with the gradual closing of psychiatric hospitals. In addition, the legislation imposed the observance of a charter of patient rights and duties as well as stricter rules for compulsory internment. In sum, in this law "mental health" amounted first and foremost, to the protection and care of psychiatry users and institutionalized persons. These principles closely followed the international standards handed down by the World Health Organization (WHO). Documents such as the Declaration of Alma-Ata (1978) established the ethical standards underlying the intended reform ${ }^{7}$.

By 2006, in order to re-launch the reform, a newly appointed working commission produced a document entitled the National Mental Health Plan (Plano Nacional de Saúde Menta) $)^{8(b)}$. This consisted of a more detailed set of guidelines aiming, once again, at the full reorganization of psychiatric care services. From its first few statements, this document brought epidemiological "evidence" to the forefront of its argumentation strategy. Opening the text, we may read that "[t]he most recent epidemiological studies show that psychiatric disorders and mental health problems have become the leading cause of disability and a major cause of morbidity in contemporary societies" (p. 5). The document further states that the burden of "mental disorders", specifically, depression, alcohol dependency and schizophrenia, have been seriously underestimated. 
In explanation, the Plan states that the "traditional approaches" solely considered the indexes of mortality linked with mental disorders, ignoring the number of years lived with "the disability caused by the illness" (doença) (p. 5). This underestimation of the burden of mental disorders was all the more preoccupying as five among the ten leading causes of disability are "mental disorders" (perturbações psiquiátricas) (p. 6). Quoting the WHO-Europe Region and the American Academy of Child and Adolescent Psychiatry, the Plan referred to one in every five children as suffering from problems of "mental health" (saúde mental), and that this number was rising (p. 6).

These excerpts demonstrate the differentiation between concepts of "mental disorder", "illness" and "problems of mental health". Nevertheless, undefined and virtually interchangeable, their differences become blurred in a single domain of phenomena. The passage that closes this section of the Plan further extends the domain of mental health:

In addition to the people who have a diagnosable disorder, many have mental health problems that may be considered "subliminal", that is, do not meet the diagnostic criteria for psychiatric disorder but are also suffering, and are thus to benefit from interventions ${ }^{8}$. (p. 5) [My emphasis; all translations from Portuguese sources are mine]

In sum, the Plan builds its own domain of intervention through a gradient of different, yet implicitly interlinked, phenomena: suffering, mental health problems, mental disorders, and mental illnesses.

The document advances the desired types of interventions, again along the lines of the WHO directives. On top of this, we find the initiatives designed to promote access to care for all persons with "mental health problems" (p. 8). A few organizational and administrative principles are then stated, for example, "taking responsibility for a geo-demographic sector, with a dimension allowing essential care in the geographical proximity of the person's place of residence" (p. 5). Among these interventions, we encounter the enhancement of user and family member participation (here without further specification; elsewhere with reference to the closing of psychiatric hospitals; p. 24), the integration of mental health into primary care, and close cooperation with the social sector on recovery and "continued care" programmes for "serious mental patients" (p. 7). The remaining sections of the Plan analyze the situation in Portugal. Underlying this analysis, there is the notion that the country still falls far short of meeting acceptable "treatment gap" indicators, as well as the principles of international organizations. Easy and universal access to basic mental health care, the centralised coordination of reference hospitals and local services, as well as the building of interdisciplinary teams - all emerge as central concerns. The Plan further expresses concern over promoting the rights of service users, especially the "right to adequate care, habitation and work" (p. 13). This concern materialized in the setting up of a Working Group on Humans Rights and Mental Health.

Lastly, the Plan defines a few target groups of users as priority. Children and adolescents deserve particular concern with the focus on prevention. Again, "serious mental patients" become the object of measures interlinked with the closing of psychiatric hospitals and their integration into facilities within "the community" (p. 21-2). At a local level, the Plan articulates the intention to develop an integrated approach across the following subdomains: the case management of "serious mental patients" by benchmark therapists; a liaison program with the family health sector, in view of tackling "common mental troubles"; a support program designed for "elderly patients"; and a suicide prevention program (p. 24).

In practice, the Plan was launched in 2008. Additionally that year, Portugal also signed the European Pact for Mental Health and Wellbeing. This is based on the assumption of a widely shared necessity for "a decisive political step to make mental health and wellbeing a key priority", reflecting in targeted interventions taking into account the diversity of risk groups in the European population ${ }^{9}$ (p. 2).

\section{Mental Health in Times of Crisis and Recession}

The Mental Health National Plan closed with a nine years calendar of initiative implementation spanning from 2007 to 2016. 2007 observed the first signs of the global financial crisis that would 
eventually lead to the so-called European sovereign debt crisis and the bailout of several Eurozone countries. The bailout of Portugal in May 2011 was followed by the fall of the Socialist government and the election of a right-wing coalition. Pressured by the European Central Bank, the European Commission and the IMF, from 2011 to 2015, the coalition applied "austerity" policies that included significant salary cuts and tax rises as well as drastic reductions to public expenditure ${ }^{10}$. At least in the government's rhetoric, "austerity" became more than a financial and economic policy. In interviews and official discourses, the Prime Minister, the Ministers of Finances and influential opinion makers diffused values of resilience to hardship and concepts of virtue linked to entrepreneurship and the reduction of consumption habits ${ }^{11}$. In reality, these values did effectively adapt and apply to the rapidly changing living conditions, with unemployment soaring in 2012 before peaking at $17.4 \%$ in 2013 and declining only slightly thereafter (according to the OECD) ${ }^{12}$. However, the younger generation bore the most serious brunt of the crisis and the austerity politics that followed, with the youth unemployment rate rising from $16.7 \%$ in 2008 to a shocking $38.1 \%$ in $2013^{13}$.

The National Mental Health Plan thus coincided with the austerity years, a coincidence that shaped its pace of implementation and set new priorities. In 2012, the Directorate-General of Health (DGH) (Direção-Geral de Saúde), the entity encharged with the Plan's implementation, issued a report acknowledging this change of context ${ }^{14}$. The DGH viewed financial constraints as both a challenge driving the reassessment of priorities and an opportunity to undertake the reforms that had proved the most difficult to undertake, in particular "the adoption of guidelines for the rational prescription of psychotropic drugs and the involvement of non-medical professionals in therapeutic programs" (p. 4). According to the $\mathrm{DGH}$, the crisis intensified the probability of a rise in the prevalence of some "mental illnesses", coupled with a surge in the suicide rate. Therefore, the new context demanded stronger investment in community services, the promotion of prevention programs targeting suicide and depression, and the development of the capacity to intervene in acute crises (p. 4).

From 2012, the expansion of rationales and procedures in GMH in Portugal underwent significant developments. A team based in Lisbon obtained the leadership of the Joint Action for Mental Health and Wellbeing, an international program involving 51 partners representing 28 EU Member States and 11 European organizations, with the aim of "building a framework for action in mental health policy at the European level"15. Launched as a development of the abovementioned European Pact for Mental Health and Wellbeing, and funded by the European Agency for Health and Consumers, the Joint Action started its work in 2013, with an agenda based on five strategic domains: 1) mental health at workplaces; 2) mental health in schools; 3 ) actions against depression and suicide, with a focus on the implementation of e-health approaches; 4$)$ community-based and socially inclusive mental health care for people with severe mental disorders; and 5) the integration of mental health in all policies ( $p$. 3). While care of persons with severe mental disorders still deserves mention, primary and targeted prevention now covers virtually the whole field of mental health. In combination with this initiative, a new institution came into being in 2015, the Lisbon Institute of Global Mental Health. Its principal functions consist of the formation of a new leadership in $\mathrm{GMH}$ and the development of a critical mass capable of issuing scientific and technical advice on the implementation of mental health programs ${ }^{16}$.

The actualized version of the National Mental Health Plan ${ }^{15}$ acknowledged the Joint Action and the then emerging Institute, viewing them as allies in the implementation of its reform program. However, in its language and scope, the Joint Action took a further step in the expansion of the concept of "mental health". For instance, while the Plan still employed the notion of "mental illness" profusely, the first major report published by the Joint Action significantly replaced it for the concept of "mental disorder" (seldom employed in the version of the Plan analysed above ${ }^{8}$ ). The Joint Action's almost exclusive focus on prevention and the promotion of mental wellbeing is testified to by a new emphasis on the concept of "Mental Health in All Policies (MHiAP)". Brought to the forefront of the project's report" ${ }^{17}, \mathrm{MHiAP}$ is defined as "an approach to promoting population mental health and wellbeing by initiating and facilitating action within different non-health public policy areas". Set as one of the main pillars of the Joint Action, MHiAP targets the "impact of public policies on mental health determinants", aiming to reduce "mental health inequalities", and promote the inclusion of mental health variables in different policy areas. Covering all administrative levels, this strategy "aims 
to highlight the opportunities offered by mental health to different policy areas, and reinforces the accountability of policy-makers for mental health impact" (p. 6).

In this article below, we analyze some of the implications of the intended expansion of the concept of mental health. At this point, we would stress the growing role of epidemiology in the reform of mental health services. Concretely, we must look at the scientific, economic and political rationales behind the epidemiological data presented as evidence and the ways in which these get communicated both to specialists and to the wider public.

\section{The New Epidemiology and the Media}

Virtually all the above documents relative to mental health reform started with epidemiological data, presented as the factual grounds to the problems requiring attention. Thus, this represents the context for understanding a key document for the globalization of mental health in Portugal, a report entitled "National Epidemiological Study in Mental Health" (Estudo Epidemiológico Nacional de Saúde Menta $)^{18}$. Published in 2013, this study was presented as part of an international enterprise, the World Mental Health Survey Initiative, undertaken by the University of Harvard and the WHO. This study was coordinated by two psychiatrists, José Miguel Caldas de Almeida, a leading international expert in the domain of GMH at the WHO (from 2013 also the leader of the abovementioned Joint Action); and Miguel Xavier, holder of a university chair in psychiatry in Lisbon. The involvement of these doctors in the design and implementation of the National Mental Health Plan and the acknowledged support of the Ministry of Health renders this study near official (p. 6). In planning since the late 1990s, this study eventually turned into the scientific umbrella for the Plan. First and foremost, the study aimed to map the prevalence of "psychiatric disorders" (perturbações psiquiátricas) in the Portuguese population. This, however, proved the entranceway into a series of other issues, in particular the degree of disability associated with disorders and the observation of their "natural history" alongside analysis of their possible causal factors. Lastly, and featuring prominently among its key problems, this epidemiological research assessed the usage of health services by individuals suffering from "psychiatric disorders" (p. 4). The study's ultimate objective was to evaluate the necessity of mental health interventions among the population with a view to developing appropriate prevention and treatment strategies. The adopted focus on objective necessities, on the one hand, and actual responses, on the other, became encapsulated in the concept of a "treatment gap", ubiquitous in the study's report.

The study attributed high scores to all "treatment gap" indicators, varying according to the gravity of disorders. Reaching $80 \%$ in cases of mild disorders, the "treatment gap" for serious mental disorders is still alarmingly high at $33.6 \%$ (p. 36). While these results are discussed in terms of access to care, emphasis is placed on prevalence rates. These show significant levels, with the highest being anxiety and phobic disorders (25.8\%) and affective disorders (19.3\%). The estimated lifetime prevalence of one psychiatric disorder in the adult population reaches $42.7 \%$, while in the younger segment of the population (18 to 34 year olds) it soars to $50.1 \%$. Compared to other countries participating in the World Mental Health Survey Initiative, the prevalence of mental disorders in Portugal proves startling. Adult lifetime prevalence $(47.4 \%)$ is surpassed only by the USA, with countries usually compared to Portugal, such as Spain and Italy, showing figures significantly below the Portuguese (respectively $19.4 \%$ and $18.1 \%$ ) (p. 30).

It is worth noting that, obtained during the 2000 s, these numbers do not reflect the consequences of the crisis on mental health. Reports preceding the National Epidemiological Study in Mental Health already pointed towards preoccupying prevalence rates of mental disorders' 18,19 (p. 137-41). Again, just after the onset of the crisis, but still before its peak, some media did signal, and with red flags, the growing public data regarding the mental health of the Portuguese. Let us then turn to the diffusion of these data in the media.

An exploratory overview of the newspaper coverage of mental health issues proves of assistance in understanding the rationales behind the $\mathrm{GMH}$ model in Portugal. The oldest reference encountered to the epidemiological survey coordinated by Caldas de Almeida dates back to $2010^{20}$. In October of that 
year, commemorating European Depression Day, an online newspaper reported a series of initiatives in the media to raise awareness of the "disease", deemed to kill 1,200 in Portugal every year. The article quoted a then "recent pilot study into the state of Portugal's mental health", revealing "that one in five citizens suffer from some form of psychiatric problem, a higher incidence than any of the other six EU countries that participated in the project".

An article published in 2011, also specifically on depression, reported high rates as agreed upon evidence ${ }^{21}$ : "Portugal is the European country with the highest rate of depression and the second in the world [after the USA], but it is estimated that one third of the population with severe mental disorders are not being treated". These statements were attributed to psychiatrist Ricardo Gusmão, coordinator of the European Alliance against Depression, who tackled the contradiction involved in the awareness of high levels of consumption of anti-depressants in Portugal and the poor mental health indicators. Allegedly, the lack of treatment for depression stems from stigma and misconceptions among general practitioners providing primary care. The psychiatrist thus defended the necessity of fighting against the "stigma" of depression in the medical profession itself. This meant, in practice, diffusing the notion that depression constitutes an "illness of the brain". Still according to the same article, Gusmão argued that people suffering from depression were not treated because of the stigma linked to antidepressants, and because of the "false belief" that antidepressants cause dependency. In this line of thought, Gusmão called for a change in the medical curricula, especially in placing the emphasis on the brain instead of focusing on psychological model. However, the same article went on to state that, according to the same European Alliance Against Depression, antidepressants sales had increased by $300 \%$.

In 2014, a study published by the WHO reported relatively low and decreasing levels of suicide in Portugal ${ }^{22}$. Confronted with these numbers, Gusmão and Álvaro de Carvalho, the latter the successor of Caldas de Almeida at the National Mental Health Plan, called into question the methodology employed by the WHO. In all probability, the suicide rate was getting underestimated. Nevertheless, they admitted that widespread recourse to anti-depressants might be playing a deterrent role with regard to suicides, especially among those left unemployed as a consequence of the prolonged recession. Social support given by family networks, particularly strong in countries such as Portugal and Spain, may also account for the low levels of suicide ${ }^{23}$. A similar argument on the underreporting of suicides was voiced in a public presentation of the official report published by the Directorate-General of Health ${ }^{24}$.

In 2015, a team coordinated by Gusmão won a grant from the European Economic Area to implement a depression and suicide prevention program. As conveyed by yet another newspaper article ${ }^{25}$, the approach adopted consisted of training "900 experts in depression" in primary healthcare centers throughout the country. These experts include general practitioners, nurses, psychologists and social workers. Furthermore, they are then to diffuse their newly acquired knowledge to three thousand and four hundred professionals in their areas. In so doing, the project aims to reach one million primary healthcare users, and, particularly, increasing among them an estimated two hundred thousand depressed persons. The principal objectives of the program feature reducing the consumption of anxiolytics and suicide prevention through correct diagnosing, continued care by a reference expert and an online platform designed for patients meeting criteria such as "refusal in taking medication". To train the experts, the team conducts an eight-hour training plan with an additional four hours of e-learning. The same article accounts for an interlinked activity undertaken by the project coordinator, aiming its expansion in the Portuguese speaking world. Gusmão - as quoted in the article - reminds us that Mozambique is the African country with the highest percentage of suicides and that Angola also has a higher suicide rate than Portugal.

While this and other programs suggest cutting-edge approaches to mental health policies, other studies and newspaper articles point towards increasing asymmetries in the field. For instance, a newspaper article published in 2015 attributed a quote to psychiatrist Luísa Figueira, then president of the Portuguese Society of Psychiatry and Mental Health (PSPMH) detailing the need to revise the National Mental Health Plan ${ }^{26}$. This leading Portuguese psychiatrist deemed the poor funding model of the system accountable for the failings in responses to the mental health necessities of the population. 
Figueira quoted both the abovementioned epidemiological study and a special edition of The Economist Intelligence Unit, published in December 2014. This survey on the quality of mental health services ranked Portugal at 28 in a universe of thirty $\operatorname{countries}^{27}$ (p. 35). Nevertheless, the article focused mostly on the study promoted by the PSPMH on the deinstitutionalizing process carried out since 2009. For instance, with regard to the closure of one of the oldest psychiatric hospitals, Hospital Miguel Bombarda in Lisbon, a study coordinated by Palha conveyed the huge asymmetries in the responses given to inmates ${ }^{28}$. While some inpatients had been transferred to "Casa do Restelo", a well-located community residence provided with human resources and appropriate infra-structures, many had been relocated to the Centro de Apoio Social do Pisão, which Palha described as a center with 320 interned persons "on a mountain more than $4 \mathrm{~km}$ distant from its nearest inhabited location" ${ }^{26}$. As already pointed out by Hespanha et al. ${ }^{4}$, both Palha and Figueira defended that the closing of psychiatric hospitals was being carried out without any real community-based alternatives. Instead of effectively "deinstitutionalized', chronic psychiatric inmates were instead being "trans-institutionalized".

The two dimensions of mental health addressed in this article - the "treatment gap" observed in the general population and the needs of persons in psychiatric institutions - encapsulate much of the ambivalence encountered in the documents on the global mental health paradigm as applied in Portugal. The ratio of this ambivalence is also easy to pin down: tackling "suffering" at its roots has preventive effects on "common mental disorders" and on "serious mental illness". Thus, from this perspective, a change of focus from the latter to the former reveals only a convergence between the economic and the health arguments.

In this light, how the National Epidemiological Study explicitly leaves the following groups out of its scope becomes highly significant: residents in houses owned by a third person; residents in fosterhouses, hospitals and psychiatric institutions; residents in military barracks; prison inmates; individuals not fluent in Portuguese; individuals without any capacity to participate in the interview; homeless persons; and, psychotic persons ${ }^{18}$ (p. 12). This restriction is justified by the study's objective of mapping undiagnosed and untreated disorders.

While deinstitutionalization and the rights of psychiatry users still figure on the intention lists of these programs, the reduction in the "treatment gap" becomes the cornerstone of both research and health policies in mental health. In this context, our contention here is that such emphasis becomes instrumental to the actual concept of mental health proposed in the study. It reads indeed that far more than the absence of mental illness, mental health cannot be dissociated from the "the wellbeing and the efficient functioning of individuals". This involves the capacity to "adapt to changes, of facing crises, establishing rewarding relationships with others and finding a purpose in life". Therefore, mental health also constitutes a key factor for social inclusion and "full communitarian and economic participation" (p. 9).

Cast in these terms, mental health proves a truly public health issue, deserving the attention of the media and politicians. Psychiatry users and institutionalized persons become a lesser priority: in a sense, they are already lost to "mental health". To nobody's particular surprise, the reform's initial drive towards both deinstitutionalization and the protection of the rights of persons with serious mental disorders gradually got pushed to the bottom of the priority list.

\section{Conclusion}

\section{From Treatment Gap to Policy Gap}

The concept of mental health has expanded since its first appearance in the Charter of the World Health Organization in 1948. Initially deferring to a concept of social and individual wellbeing, with regard to which societies and states have moral responsibility, in the last few decades the definition of "mental health" looks increasingly receptive to the productivity and efficiency arguments. As an example, at Joint Action's website ${ }^{29}$, among its first few statements, we may read the following: "Until 2020 , the cost of depression will be tripled. $88 \%$ will be indirect, due to productivity losses". 
The impact of health on economics certainly deserves to be considered. Serious questions arise, however, when social suffering becomes translated into individual mental disorders. The problem becomes all the more alarming as this re-writing of social suffering into mental disorders is applied to hierarchize the subjects of psychic suffering deserving political attention along a priority scale defined in terms of economic utility. The diffusion of the high prevalence rates of depression and other mental disorders in the media seeks public support for this redefinition of suffering. The fundamental message thus passed is that common mental disorders are individual health issues, the aggregate of which constitute a major public health problem: the more objective (in the terms of epidemiology), the more real; and the more prevalent, the more important.

Within this line of thought, it is highly significant that the quoted epidemiological study eliminates social context in the construction of its data. And it is no less revealing that the same study leaves "psychotics", prison inmates and institutionalized persons, among other groups, outside the "mental health" universe. Indeed, the evidence provided by Hespanha et al. ${ }^{4}$ and by Palha ${ }^{28}$ strongly suggest that, despite the GMH approaches typical of the "center", as defined by Santos ${ }^{3}$, the lives of many of those belonging to these groups seem closer to the above description provided by Kleinman ${ }^{1}$. At any rate, the emerging $\mathrm{GMH}$ paradigm carries the risk of creating new forms of invisibility regarding frequent psychiatry users, institutionalized persons and psychiatric survivors. Rather than fostering their agency and actual rights, ethical declarations and charters of user rights can, in this context, function as an ideological screen for the ongoing poor living conditions of many of these persons and the degradation of the concrete ways in which they experience citizenship.

It is still not clear whether the Mental Health in all Policies approach will prove yet another shortlived paragon with scant impact on social realities or, in the worst case scenario, a vehicle for further medicalizing life and rendering social suffering ever more adaptable to global capitalism. The high levels of consumption of psychotropic drugs and the emphasis on financial and economic arguments, rather than ethical concerns, give room to this pessimistic scenario. Yet, at this point, we should also consider the possibility of a more positive outcome, in particular, the potential of the Mental Health in all Policies approach to impact on social policies and contribute to changes in political culture. Knowledge on the impact of policies on mental health can be helpful in creating awareness, first, that political decisions result in consequences in terms of the psychic suffering of individuals; and, second, that these consequences are to be approached from a value-driven public health perspective.

In advanced democratic societies, the engagement of psychiatry users in the design of mental health policies must feature prominently among the values underlying the design of health and social care services. However, the active engagement of users remains not only absent from healthcare reforms, but looks increasingly overshadowed by the $\mathrm{GMH}^{\prime} \mathrm{s}$ emphasis on medical expertise as the sole source of legitimacy in the design and management of services.

\footnotetext{
Aknowledgments

The author gratefully acknowledges the financial support of the exploratory project "The Fabric of Mental Health. Medical Power, Secularity, and the Psychotherapeutic Field in Portugal (1940s-1990s)." funded by the Portuguese Foundation for Science and Technology (FCT) IF/01589/2013/CP1164/CT0005.

The author would also like to thank Sílvia Portugal and the reviewers for their helpful comments for the improvement of this manuscript.
} 


\section{References}

1. Kleinman A. The art of medicine. Global mental health: a failure of humanity. Lancet. 2009; 374(9690):603-4.

2. Kirmayer LJ, Pederson D. Toward a new architecture for global mental health. Transcult Psychiatry. 2014; 51(6):759-76.

3. Santos BS. Pela mão de Alice. O social e o político na pós-modernidade. Porto: Afrontamento; 1994.

4. Hespanha P, Portugal S, Nogueira C, Pereira JM, Hespanha MJ. Doença mental, instituições e famílias. Os desafios da desinstitucionalização em Portugal. Coimbra: Almedina; 2012.

5. Horwitz AV, Grob GN. The checkered history of american psychiatric epidemiology. Milbank Q. 2011; 89(4):628-57.

6. Lei n 36/98 de 24 de Julho. Lei de Saúde Mental. Diário da República. 24 Jul 1998: série A. [cited 7 Oct 2016]. Available from: http://www.dgpj.mj.pt/DGPJ/sections/ leis-da-justica/livro-iv-leis-criminais/pdf4/I-36-1998/downloadFile/file/L 36 1998. pdf?nocache $=1182172855.09$

7. World Health Organization. Declaration of Alma-Ata. Geneva: WHO; 1978 [cited 7 Oct 2016]. Available from: http://www.who.int/publications/almaata_declaration_ en.pdf?ua $=1$

8. Ministério da Saúde (PT). Coordenação Nacional para a Saúde Mental. Plano Nacional de Saúde Mental. Resumo Executivo, 2007-2016. Lisboa: Alto Comissariado da Saúde; 2008 [cited 7 Oct 2016]. Available from: http://adeb.pt/ficheiros/ uploads/02a75f2c0346f49717d171c23b7f56a2.pdf

9. Slovenian Presidency of the European Union. European Pact for Mental Health and Well-being. Brussels: European Union; 2008 [cited 7 Oct 2016]. Available from: http:// ec.europa.eu/health/ph_determinants/life_style/mental/docs/pact_en.pdf

10 Costa A, Caldas JC. A União Europeia e Portugal entre os resgates bancários e a austeridade: um mapa das políticas e das medidas. In: Reis J, coordenador. A economia política do retrocesso. Coimbra: Almeida; 2014. p. 72-107.

11. Caldas JC, Almeida JR. Narrativas da crise no jornalismo económico. Cadernos do Lisboa: Observatório sobre Crises e Alternativas; 2016 [cited 7 Oct 2016]. Available from: http://www.ces.uc.pt/observatorios/crisalt/documentos/cadernos/CadernoObserv_VII mar2016.pdf

12. OECD. OECD Data. How does Portugal compare? September 2014 [Internet] [cited 7 Oct 2016]. Available from: http://www.oecd.org/portugal/EMO-PRT-EN.pdf.

13. OECD. OECD Data. Unemployment rate [Internet] [cited 7 Oct 2016]. Available from: https://data.oecd.org/unemp/youth-unemployment-rate.htm.

14. Ministério da Saúde (PT). Direção-Geral de Saúde. Programa Nacional para a Saúde Mental: Orientações Programáticas. Lisboa: Ministério da Saúde; 2012 [cited 7 Oct 2016]. Available from: https://www.google. $\mathrm{pt} / \# \mathrm{q}=$ Programa +Nacional + para +a+Saúde+Mental: + Orientações + Programáticas

15. Joint Action. The joint action: mental health and wellbeing: why investing in mental health in Europe [Internet] [cited 7 Oct 2016]. Available from: http://www. mentalhealthandwellbeing.eu/the-joint-action.

16. Lisbon Institute of Global Mental Health [Internet] [cited 7 Oct 2016]. Available from: http://www.lisboninstitutegmh.org/institute. 
17. Joint Action. Joint Action on Mental Health and Well-being. Mental Health in All Policies. Situation analysis and recommendations for action [Internet] [cited 7 Oct 2015]. Available from: http://www.mentalhealthandwellbeing.eu/publications.

18. Almeida JMC, Xavier M, coordenadores. Estudo epidemiológico nacional de saúde mental. $1^{\circ}$ Relatório. Lisboa: Faculdade de Ciências Médicas da Universidade Nova de Lisboa; 2013.

19. Gusmão RM, Xavier M, Heitor MJ, Bento A, Almeida JMC. O peso das perturbações depressivas. Aspectos epidemiológicos globais e necessidades de informação em Portugal. Acta Med Port. 2005; 18:129-46.

20. First National Campaign to Fight Depression [Internet]. 2010 [cited 7 Oct 2016]. Available from: http://www.theportugalnews.com/news/first-national-campaign-to-fightdepression/4256.

21. Portugal is the European country with the highest rate of depression. Portuguese American Journal. 30 Sep 2011 [Internet]. [cited 7 Oct 2016]. Available from: http:// portuguese-american-journal.com/portugal-is-the-european-country-with-the-highestrate-of-depression/.

22. World Health Organization. Preventing suicide: a global imperative. Geneva: World Health Organization; 2014 [Internet]. [cited 7 Oct 2016]. Available from: http://www. who.int/mental_health/suicide-prevention/world_report_2014/en/.

23. Faria N. OMS diz que suicídios em Portugal diminuíram, especialistas negam [Internet]. Público. 5 Sep 2014 [cited 7 Oct 2016]. Available from: https://www.publico.pt/portugal/ jornal/oms-diz-que-suicidios-em-portugal-diminuiram-especialistas-negam-28793940.

24. Direcção-Geral de Saúde (PT). Saúde Mental em números - 2013. Lisboa: DirecçãoGeral de Saúde; 2013 [Internet]. [cited 7 Oct 2016]. Available from: https://www.dgs. pt/estatisticas-de-saude/estatisticas-de-saude/publicacoes/portugal-saude-mental-emnumeros-2013.aspx.

25. Gomes C. Programa de formação vai criar 900 "peritos em depressão" nos centros de saúde. Público. 26 Mai 2015 [cited 7 Oct 2016]. Available from: https://www.publico. $\mathrm{pt} /$ sociedade/noticia/programa-de-formacao-vai-criar-900-peritos-em-depressao-noscentros-de-saude-1696815.

26. Santos RB. Fecho dos hospitais psiquiátricos "agravou problemas dos doentes" [Internet]. Público. 14 Mar 2015 [cited 7 Oct 2016]. Available from: https://www.publico. pt/2015/03/13/sociedade/noticia/encerramento-dos-hospitais-psiquiatricos-agravouproblemas-de-muitos-doentes-1689023.

27. The Economist / Intelligence Unit. Mental Health and Integration. Provision for supporting people with mental illness: a comparison of 30 European countries. 2014 [cited 7 Oct 2016]. Available from: https://www.eiu.com/home.aspx.

28. Palha F. Trajectórias pelos cuidados da saúde mental. Parte I: o processo de desinstitucionalização psiquiátrica em Portugal: da análise objetiva dos factos às perceções de utentes, familiars/ cuidadores, técnicos. Porto: Encontrar+se/ Sociedade Portuguesa de Psiquiatria e Saúde Mental; 2015 [cited 7 Oct 2016]. Available from: http://www. encontrarse.pt/Default.aspx?Tag $=$ CONTENT\&Contentld $=2213$.

29. The Joint Action [Internet] [cited 7 Oct 2016]. Available from: http://www. mentalhealthandwellbeing.eu. 
Marques TP. El foso de políticas. La salud mental en un país semi-periférico (Portugal, 1998-2016). Interface (Botucatu). 2017; 21(63):787-98.

Este artículo analiza el impacto del paradigma hegemónico de la salud mental (SMG) en Portugal. Se argumenta que la SMG en Portugal promovió un cambio de prioridades en las políticas de salud, favoreciendo la prevención y el tratamiento de los desórdenes mentales comunes en perjuicio del proceso de desinstitucionalización. Al difundirse en los medios, este modelo tiene efectos negativos, puesto que contribuye para la medicalización del sufrimiento social, el escalonamiento de áreas de intervención de acuerdo con criterios utilitaristas y el riesgo de una mayor invisibilidad de los usuarios con diagnósticos psiquiátricos graves. Sin embargo, el enfoque de la SMG en el impacto de las políticas sociales sobre la salud mental representa una nueva oportunidad para enfrentar políticamente el sufrimiento social. Caracterizado como país semi-periférico, Portugal puede ser representativo de tendencias observables en países similares.

Palabras clave: Globalización. Salud mental. Reformas psiquiátricas. Epidemiología psiquiátrica. Derechos humanos. 